\title{
ALTERING THE USE OF AGRICULTURAL INTO CONSTRUCTION LAND - PRACTICE AND TRENDS
}

\author{
Milan Počuča ${ }^{1}$, Bojana Drašković
}

\begin{abstract}
Summary
Preservation of agricultural land as an imperative of prosperity of agriculture of the Republic of Serbia needs to be observed through causal questions as well, such as change of purpose of agricultural land into construction land, which is necessarily followed by conversion, a decade-long problem. Insufficiently resolved current questions of the aforementioned within legislative framework open up the possibility for improper use and exploitation of agricultural land. It is necessary to regulate the issue of conversion of construction land by legislative regulations i.e. altering use rights into property rights on construction land, and by doing so, open the way to investments in the Republic of Serbia. With the analysis of the effects of conversion and the adoption of a special law on this issue, construction activity would further prosper. The aim of this paper is to assess adequately the current problems of consumption, preservation and actual implementation of transferring agricultural land to construction land, with a view of the facts, practices and tendencies.
\end{abstract}

JEL: $K 11, Q 15$

Key words: agricultural land, construction land, repurposing, conversion, urbanization.

\section{Introduction}

Seeing as how Republic of Serbia extends to about 8,840,000 acres, out of which 6,000,000 acres are agricultural land, we note that $70 \%$ of its total area is exploited for agricultural purposes. Moderate continental climate and favorable climate conditions represent a prerequisite for development of agriculture, and therefore the prosperity of agricultural land. However despite this fact, the "disappearance" of agricultural land represents an often occurrence in the Republic of Serbia. Annually between 6,000 and 30,000 hectares

1 Počuča Milan, Ph.D., Full Professor, University Business Academy, Law Faculty for Economics and Justice in Novi Sad, Geri Karolja Street no. 1, 21000 Novi Sad, Serbia, Phone: +381 21400 499, E-mail: pocucabmilan@gmail.com

2 Drašković Bojana, Ph.D., Associate Professor, University Union Nikola Tesla, Faculty for Construction management, Cara Dušana Street no. 62-64, 11000 Belgrade, Serbia, Phone: +381 112180 287, E-mail: bdraskovic@krstarica.com

EP 2015 (62) 2 (497-511) 
of agricultural land "disappear" due to urbanization, infrastructure construction and excavation sites, therefore it is necessary to adequately protect the best land through legislative framework with the application of modern technologies for preservation without disturbing its natural properties. Aware of the fact that in recent years agricultural land has not been adequately treated and used, and seeing as how positive legal regulations, namely the Agricultural Land Law (Official Gazzete of the Republic of Serbia, no. 62/2006, $65 / 2008$, - other law and 41/2009) dictate otherwise, we come to a conclusion that Serbia has a huge percentage of neglected and unused land. Ignoring concerns on the quality and consumption of agricultural land in the legitimate manner leads to growth of percentage of uncultivable surfaces.

"Accelerated investment in the transition process, which is shaking the entire geographical system of Serbia, is primarily directed towards inexpensive agricultural land, especially around big cities." (Stojkov, 2007)

It is necessary to adopt adequate laws and bylaws and documents that would be in favor of the stand that it is necessary to invest and preserve agricultural land as the primary item for prosperity of the Republic of Serbia." In an effort to be as clear, traces the direction of future reforms of the agricultural sector within external and internal challenges that it faces, as well as to define the measures and activities for Reconstruction and activate the development potential of rural areas, the Ministry of Agriculture and Environmental the environment has initiated the preparation of a strategic document." (Ministry of Agriculture, Forestry and Water Management of the Republic of Serbia, Draft Strategy for Agriculture and Rural Development of Serbia 2014-2024. November 2013, Official Gazette of Republic of Serbia (OGRS), no. 85/2014)

\section{Methodology and Data Sources}

In the course of recent years, current legislation of the Republic of Serbia in the area of construction and agriculture exists despite the under-resolved current issue of preserving agricultural land as a necessity for prosperity in the RS.

Goals - The goal of this paper is to perceive the necessary factors which necessarily lead to the solving of current problems of preserving agricultural land with the possibility of performing change of utilization from agricultural to construction land in the RS. With an overview of the state of facts and legal framework of the RS in these areas we find that the best way to point out the necessity of systematization and appropriate use as well as exploitation of agricultural land when it comes to Republic of Serbia is through the abovementioned methods as well as access roads to the current issues.

Methodology - When we were applying dogmatic-normative method during the period of writing the paper, we found that an indication was made on solutions for applying certain legal postulates as well as the layout of legal regulations in the fields of agriculture and construction when it comes to the repurposing of agricultural land to building land. Through this method it was possible to identify the necessary legal interventions in the positive legislation of the RS in these areas when it comes to preservation of agricultural land and the issue of transferring 
the same. Usage of an analytical method was to analyse the effects of existing positivelegal solutions on the matter and thereby justify the interventions necessary to amend the applicable legal provisions. Through usage of comparative method when analysing current laws in the field of civil engineering on one hand, and legal solutions in the field of agriculture on the other, findings that corroborate the doubt of inadequacy of legal solutions in terms of preserving agricultural land as a primary parameter of agricultural development in the RS arose. Usage of the above methods while writing this paper indicated that the preservation of agricultural land is an imperative for the prosperity of the Republic of Serbia, which is viewed through causal issues of repurposing of agricultural to construction land, with conversion as the current problem.

Data Sources - Valid legal documents were analysed in these areas, (Law on Agricultural and Rural Development, OGRS no. 41/2009 and 10/2013; Agricultural Land Law, OGRS, no. 62/2006, 65/2008, - other laws and 41/2009; Law on Forests, OGRS no. 30/2010; Law on Public Property, OGRS no. 72/2011, 88/2013 and 105/2014; Law on Planning and Construction, OGRS no. 72/2009, 81/2009 - corr., 64/2010 - decision US, 24/2011, 121/2012, 42/2013 - decision US, 50/2013 - decision US, 98/2013 - decision US, 132/2014 and 145/2014) which have, alongside articles on legal solutions, shown the best process of transformation of agricultural into construction land, with the conversion as ancillary question, as well as a review on the prosperity of agricultural land and its tendencies.

\section{Spatial and urban planning - general and sectoral policies}

Spatial and urban planning needs to be viewed through one of the forms of social regulation mechanisms of spatial development of the Republic of Serbia. Planning, general and sectoral policies of the Republic of Serbia have, through market mechanisms of social control i.e. through social systems management according to preset criteria determined and set the standards and norms of urban and spatial planning. General goals with the analysis of existing resources for their preservation through prejudicial strategy for the way of managing these processes for the achievement of objectives represent a rough definition of spatial planning with its intensification after the Second World War. It would be beneficial to state that the first law which referred to provisions and determined the necessity for cities to have their expansion plans was passed in Sweden in 1874.

The reason for necessity of plans that will regulate the area were represented through different objectives, and are best viewed through justification by political-economic and social demands of socio-political and social organization of a country, with necessary processes of urbanization and industrialization. Spatial planning topic at its inception was represented in the Construction Law of the Kingdom of Yugoslavia in 1931 and was at the time separated from the construction topic.

In developed countries, for planning spatial and urban prosperity a method which characterizes the functioning of the system rather than development as growth instead of quality changes is applied. Implementation of this method exclusively relates to the planning and realization of space with the necessary communication activity, and in methodological sense, ecological 
and economic and social satisfaction in applying these methods. In order for a space to be urbanized adequately with the adoption of urban planning documents we must satisfy historical, as well as physical and social aspects.

The current Law on Planning and Construction (OGRS no. 72/2009, 81/2009 - corr., 64/2010 - decision US, 24/2011, 121/2012, 42/2013 - decision US, 50/2013 - decision US, 98/2013 - decision US, 132/2014 and 145/2014) with its Article 3 lays down the principles for development and use of space which the legislator has, in a purposeful way integrated in the text of the law and indicated the necessity of applying through their enumeration.

"Planning, development and space use is based on the following principles:

1) Sustainable development through an integrated approach in planning;

2) Balanced territorial development;

3) Rational usage of land by encouraging measures of urban and rural renewal and reconstruction;

4) Rational and sustainable usage of non-renewable resources and optimal usage of renewable resources;

5) Protection and sustainable usage of natural resources and immovable cultural property;

6) Prevention of technical and technological accidents, protection from fire and explosions, protection from natural disasters, elimination of climate change causes;

7) Planning and spatial planning for defence purposes for the country;

8) Compliance with European regulations and standards in the field of spatial planning and space development;

9) Improvement and usage of information technologies which contribute to an improvement of efficiency and effectiveness of public administration in the business of construction;

10)Participation of the public;

11)Preservation of customs and traditions;

12)Preservation of the specificity of the landscape

13)Horizontal and vertical coordination."

(OGRS, art. 3, no. 72/2009, 81/2009 - corr., 64/2010 - decision US, 24/2011, 121/2012, 42/2013 - decision US, 50/2013 - decision US, 98/2013 - decision US, 132/2014 and $145 / 2014)$.

\section{Conversion of agricultural into construction land}

„Industrial agriculture is unhealthy for the natural environment, climate, our bodies and for the rural economy", (Union of Concerned Scientists, 2014).

Conversion of agricultural into construction land represents the hottest topic in the recent years in Serbia with analyzing the consequences of "imperceptible" changing in the public eye. The essential problem of converting agricultural into construction land, i.e. change of purpose of agricultural land could be observed through the obvious fact that in the 
past decade or two, over 200,000 acres of agricultural land has had its purpose changed. Even though the aforementioned is the global trend, with justification of the necessity of infrastructure development at the expense of rural areas and the distribution of the population and respectively their activities necessary for urban development, it leads to withering of large areas of agricultural land at the expense of creation of construction sites. In order for the small and medium-sized agricultural holdings in Serbia to be able to improve their physical and economic performance and become more competitive, it is necessary and perhaps most important for farmers to actively engage in the elimination of their numerous internal constraints, which "lies" in mentality and underdeveloped awareness about ways of future development” (Paraušić, Cvijanović, 2014).

"The main problems of agriculture in Serbia are small and scattered parcels of unfavorable form for agricultural exploitation" (Marošan, Šoškić, 2006).

Current Law on agricultural land makes a clear classification of agricultural land in relation to its quality and it represents the primary parameter for estimation and analysis of the same through strategic assessment of whether the land requires special treatment or not. A very important aspect of repurposing agricultural land is bringing intentions of the obtained construction land in relation to aspects of future construction, and it is important to understand if whether in certain land area, now construction, after the procedure of repurposing will a residential-commercial building be built or an industrial plant which will indicate a variable cost of investments depending on the purpose of the future facility. When we talk about the purpose and manner of construction planning, we must bear in mind that:

"According to the purpose facilities in agriculture can generally be divided into: 1) Facilities for livestock production, 2) Facilities for the storage, maintenance and repair of agricultural machinery and 3) Facilities for preservation and processing of agricultural products"' (Tica et al., 2009).

With the adoption of planning documents, which constitute repurposing ofland, it subsequently leads to changes in its value, often tenfold. What leads us astray as observers of the process of repurposing is that taking into account the bigger picture we understand that the public sector does not benefit based on the factual situation that agricultural land is repurposed and that it is necessary to protect the public interest in this direction and reduce the space for wrong doing. "Protection of land includes the protection of agricultural land, protection of construction land, mining, geological exploration, and others" (Lilić, 2010). Agricultural Land Law regulates planning and protection of agricultural land and it determines Administration for use of agricultural land.

Any agricultural land which is in accordance with positive legal regulations of the Republic of Serbia is provided or designated as construction land, i.e. planning documents have made possible the repurposing of agricultural into construction land which will exclusively be used for agricultural production until the end of the procedure of reaching the planned purpose. "Agricultural land is matter of general interest and as such protected by Agricultural Land Law, by which the society had decided to protect one of its natural resources and define its purpose" (Avramović, 2004). "By region, the highest percentage of agricultural land is used in Vojvodina (95.70\%), followed by the Belgrade region (91.87\%), Region Sumadija and 
Western Serbia (87.78\%) and Region of Southern and Eastern Serbia (77.36\%)", (NikolićĐorđić, Mutavdžić, 2014).

Citing the Article 15 of the Law on Agricultural Land, it is stated that - "Agricultural land is used for agricultural production and can't be used for any other purpose except in cases and under the conditions stipulated by this law," we see that for the repurposing of agricultural land it is necessary to obtain consent.

In the abovementioned law, we find a foothold that for the consent to be obtained, it is necessary to submit proof of ownership or the right to use agricultural land, as well as proof of payment of the administrative fee, followed by the note from agricultural inspectors on the current situation and the use of land as well as a project for recultivation if repurposing is done for a limited time. Repurposing of agricultural land is only made possible with payment of necessary fees, which of course refers to compensation for the repurposing of agricultural land and its use for non-agricultural purposes. The fee is paid at $50 \%$ of the market value of agricultural land on the day of submission of application for repurposing. (See more: Agricultural Land Law, SGRS, art. 25, no. 62/2006, 65/2008 - other law and $41 / 2009)$. Fee in the amount of $20 \%$ of the market value of construction land for repurposing purposes shall be paid on the basis of Article 23 of the said law, paragraph 1, point 3, in all those cases where the general interest is determined as the necessity to change the use with payment of adequate compensation, which in this case is in percentages. Agricultural Land Law and the obligation to pay the fee for repurposing provides in Article 25 what is necessary to be submitted with the request as well as the fact that the obligation of payment and the amount is determined by the decision of the municipality or the City Administration at the request of an interested person or on the order of agricultural inspectors. Agricultural Land Law requires that the request be submitted with the following:

1. Proof of ownership or the right to use the agricultural land;

2. A copy of the plan of the cadastral parcels;

3. Excerpt from the corresponding urban plan on the purpose of cadastral parcels;

4. Approval of the Ministry for repurposing of agricultural land referring to cases where the agricultural land can be used for non-agricultural purposes, namely for creating artificial meadows and pastures on agricultural farmland of 4th and 5th cadastral classes as well as the forest regardless of the class of land, applied as well to the issue of exploitation of mineral resources, respectively on the disposal of hazardous and harmful substances on agricultural land for a limited period of time on a previously obtained receipt of approval from the ministry with a proof of payment of the fee for repurposing of agricultural land.

Means generated from the fee for repurposing represent an income to the budget of the Republic of Serbia in the amount of $60 \%$ while $40 \%$ are revenues from the local governments on whose territory, the agricultural land whose purpose is changing, is situated.

Exemption from payment of fees for repurposing is foreseen in Agricultural Land Law (See more: Agricultural Land Law, OGRS, art. 26, no. 62/2006, 65/2008 - other law 
and 41/2009) and it is necessary to specify that interested person, with the request for determining the grounds for exemption from paying the fee submits proof of ownership or the right to use the agricultural land, as well as information about the area for which repurposing is being done, then the conceptual design as well as a copy of the cadastral parcel. In a case of construction of family housing facility it is necessary to submit data on housing conditions as well as members of the family household.

Agricultural Land Law predicts the adoption of agricultural basis of the Republic of Serbia (See more: Agricultural Land Law, OGRS, art. 7, no. 62/2006, 65/2008 - other law and 41/2009) and the autonomous region as a planning document that must comply with all other planning documents of the Republic of Serbia and their compliance is understood. Preservation of agricultural land with the necessary processes for prevention of destruction through development and implementation of projects for protection and regulation of agricultural land with a meaningful display of exploitation, presents the basis of application of these planning documents. Justification for adoption and insisting on implementation of agricultural bases can be found in performing the evaluation of suitability for the development and use of agricultural land with an analysis of the level of endangerment as well as creating the necessary conditions for the application of technical-technological and scientific developments in this area. Creation of a long-term strategy of agricultural development in relation to the overall economic and social situation in our country is based on an analysis of the ecological and cultural-historical development of Serbia.

European agricultural policy over the past decade encourages the development of agriculture through incentives and subsidizing farmers per acre and thus stands in the way of degradation of agricultural land in the EU (Karolić, 2012).

Through the available statistical data of the Republic of Serbia, through comparative analysis of domestic agricultural holdings and strategic documents in the field of agriculture, rural development and the standard of living in the REPUBLIC OF SERBIA stand out significant features and characteristics of small and medium agricultural holdings in the above mentioned territory (The Draft Strategy for Agriculture and Rural Development of Serbia 20142024, November 2013, Ministry of Agriculture, Forestry and Water Management of the Republic of Serbia, Official Gazette of Republic of Serbia (OGRS), no. 85/2014, National Rural Development Program 2011-2013 of the Republic of Serbia, Official Gazette of Republic of Serbia, no. 15/2011)

\section{Use of agricultural land}

As we mentioned in the paper, by positive legal regulations the owner or the user of agricultural land is required to cultivate the agricultural land regularly as well to treat the land with due diligence and following the rules of good agricultural practices. Regarding the use of agricultural land owned by the state, the use can be performed according to the annual program of protection, organization and use of agricultural land, brought upon by the local government. Article 61 of the Agricultural Land Law stipulates that state owned agricultural land could be submitted to usage without payment of fees to educational, 
institutions of high education and social institutions in areas appropriate to the activities they are involved with. State owned agricultural land can be given for usage to legal bodies and persons for non-agricultural production for a fee, and the Government of the Republic of Serbia defines and prescribes the conditions, methods and procedures for granting state owned agricultural land for usage in non-agricultural purposes. In addition to providing opportunities for the use of state owned agricultural land to disposal and management, the land can be leased if the annual program of protection, organization and usage of agricultural land plans such an activity. State owned agricultural land is leased by public announcement and initial price for lease in the first round may not be lower than $100 \%$ of the market lease for the area in which the land is located, while in the second round it cannot be lower than 70\% of market lease (See more: Agricultural Land Law OGRS, art. 64, no. 62/2006, 65/2008 - other law and 41/2009). Upon completed payment of lease achieved at public auction, ministry and the lessee conclude a Contract on the lease of state owned agricultural land.

\section{Revenue on state owned agricultural land}

Agricultural Land Law (See more: Agricultural Land Law, OGRS, art. 72, no. 62/2006, 65/2008 - other law and 41/2009) provides that state owned agricultural land can't be alienated, but the next article of the said law provides that replacement of state owned agricultural land can be converted, i.e. can be replaced for agricultural land owned by individuals and legal entities in the case of enlarging of agricultural land owned by the state. This refers only to cases where state owned agricultural land and agricultural land owned by individuals and legal entities which are replaced have the same market value. It would be beneficial to note that the estimate of the market value of agricultural land is based on data obtained from the competent authority in whose area the land is assessed. Law on Planning and Construction predicts the repurposing of agricultural into construction land and states that the construction land is the land designated by law or a planning document for the construction and usage of buildings as well as the land on which buildings were constructed in accordance with the law. Law on Planning and Construction provides the fee to be paid for the repurposing of agricultural into construction land in case it is foreseen by a special law. Construction land is used exclusively according to the purpose as set forth by a particular planning document. The aforementioned law provides that the purpose of land and way of exploitation of the land is set by planning document while predominant usage of the land is a way of exploiting the land for different purposes, out of which one is predominant (See more: Law on Planning and Construction, OGRS, art. 3, no. 72/2009, 81/2009 - corr., 64/2010 - decision US, 24/2011, 121/2012, 42/2013 - decision US, 50/2013 - decision US, 98/2013 - decision US, 132/2014 and 145/2014 - principles for the development and usage of space). Bu putting in effect the planning document which regulates the repurposing of agricultural into construction land, landowners is entitled by the rights and obligations as stipulated by the Law on Planning and Construction as well as all of its bylaws. The above mentioned is applied regardless of the fact that the body responsible for the registration of property and rights has not performed the change in the public book on property records. We state that until bringing the land to the planned purpose it may be used for other purposes. 
Construction land can be in all forms of ownership which implies that it can be the property in turnover, stating that in case that construction land is in public ownership, it can be in turnover only under the conditions prescribed by positive legal regulations to which it relates. The right to lease the construction land to public ownership is regulated by Article 86 of the Law on Planning and Construction, where it is stated that the construction land in public ownership can be leased for the construction of facilities for which a building permit is issued temporary as well as in the case of implementation of projects that are of importance to the Republic of Serbia. The lease agreement is concluded for a definite period of time which is no longer than 5 years.

Repurposing of agricultural into construction land is exclusively made on the basis of a planning document by which the intended repurposing is foreseen. The body responsible for the adoption of the planning document shall, within 15 days of its entry into force submit to the body in charge of cadastres the document that contains the list of all cadastral parcels whose purpose changed. The competent authority shall conduct a resulting change and will compile a note on the obligation to pay the compensation for repurposing. This notice of the obligation to pay the compensation for repurposing of agricultural land is stated in a database of realestate cadastre, where the proof of ownership of property is obtained. Until the land is changed from agricultural in the building above it can be used for agricultural production. On the basis of the Law regulating agricultural landowner of the cadastral parcel where the repurposing of agricultural into construction land has taken place is obliged to pay compensation for the repurposing prior to the issuance of building permits. During the construction of facilities that are of importance for the Republic of Serbia as well as for the construction of public facilities in accordance with the program of development of construction land when the tax payer is the Republic of Serbia, the fee for repurposing of agricultural into construction land is not paid as provided in the Law on Planning and Construction (See more: Law on Planning and Construction, OGRS, art. 88, par. 8, no. 72/2009, 81/2009 - corr., 64/2010 - decision US, 24/2011, 121/2012, 42/2013 - decision US, 50/2013 - decision US, 98/2013 - decision US, $132 / 2014$ and 145/2014).

Repurposing of forestland into construction land is foreseen by the Law on Planning and Construction and the Law on Forests (Law on Forests, OGRS, no. 30/2010) whereas the change is done solely on the basis of a planning document that predicts repurposing forest to construction land. From the date of putting in effect of this planning document, the landowner is entitled to all the rights of the owner of the construction land and in accordance with the Law on planning and construction, i.e. with Article 89 of the said Act. It is necessary to state that the owner of the cadastral parcel which has been changed from forest to construction land is obliged to pay compensation for the change prior to the issuance of a building permit and in accordance with the law governing the maintenance of forestry.

\section{Construction land}

Construction land is land that can be developed or undeveloped, i.e. if we talk about developed land it refers to land on which facilities intended for permanent and regular use are built, but 
if we speak of undeveloped land we understand it as land without constructed buildings, or if they are constructed they certainly are without a building permit or have a temporary status. Developed construction land is the one equipped for construction and usage, with public utilities whereas the underdeveloped land is to its contrary. Construction land that is not regulated in terms of planning and construction Law and is located in the coverage of the planning document on the basis of which location conditions may be issued, it can be equipped with means of both individual and legal bodies. The very concept of construction land includes the preparation and equipping, as Article 93 states.

"Preparation of land includes exploratory works, development of geodetic, geological and other bases, preparation of planning and technical documentation, programs for land development, resettlement, removal of buildings, terrain reclamation and other works.

In addition to the works referred in the paragraph 2 of this Article, in areas which were exposed to war operations, check up of the existence of residual explosive devices, in accordance with the law shall be performed.

Land equipping includes the construction of utility infrastructure and construction and renovation of public purpose.

"Law on Planning and Construction explicitly states and foresees sources of financing for development of construction land by Article 95:

Finances for regulating construction land is provided from funds raised from:

1) Taxes on Land development;

2) Lease on construction land;

3) Alienation or exchange of construction land;

4) Conversion of lease rights into property rights, in accordance with this Law;

5) Other sources in accordance with the law."

(Law on Planning and Construction, OGRS, art. 95, no. 72/2009, 81/2009 - corr., 64/2010 - decision US, 24/2011, 121/2012, 42/2013 - decision US, 50/2013 - decision US, 98/2013 decision US, 132/2014 and 145/2014).

The taxes for land development are paid by the investor.

Alienation of construction land in public ownership is implemented through public auction under market conditions. Alienation of construction land is followed by the exchange of properties whereas the conditions, manner and procedure of exchange are established by the Government of the Republic of Serbia.

Construction land in public ownership cannot be alienated or leased if not rendered or is not foreseen through a planning document based on which building permits will be issued. Owner of construction land in public ownership specify in detail all the conditions of the procedure and the content of the contract for lease or alienation of construction land. Law on Public Property (Law on Public Property, OGRS, no. 72/2011, 88/2013 and 105/2014) 
and its provisions relating to the acquisition of property in public ownership and provisions related to acquisition of property in public ownership. It is necessary to specify that the Law on Planning and Construction (See more: Law on Planning and Construction, OGRS, art. 100, no. 72/2009, 81/2009 - corr., 64/2010 - decision US, 24/2011, 121/2012, 42/2013 - decision US, 50/2013 - decision US, 98/2013 - decision US, 132/2014 and 145/2014) provides that the land in public property may be alienated or leased by direct negotiation and itemizes with all of the cases in which this can be achieved. When it comes to concessions construction land can be leased even without compensation for the time period as provided by the concession contract.

Land for regular usage of facilities is the land around the facility itself that meets the conditions for forming of building lots in accordance with the Law on Planning and Construction, and which after the procedure becomes a cadastral parcel. If in the process of determining the land for the regular use of the facility it is assured that the area of the cadastral parcel represents land for regular use, the owner of the existing facility, located on the cadastral parcel acquires the right of ownership by direct negotiations at the market price. If the land is less than the cadastral parcel on which the building is built and in case that it is impossible to form a separate building parcel, the owner of the land may alienate the remaining part by direct negotiation at market price. "It is essential that the level, standards and procedures in managing and exploiting the land adjust to the financial situation, capabilities, institutions etc. within reasonable balance between cost and benefit" (Aleksic, Marošan, 2002).

\section{Converting rights to use into property rights on construction land without compensation}

Seeing as how ownership right on cadastral parcel is entered in favour of the person registered as the owner of the building or a facility that is located on that land, consequently the right to use the construction land turns into a property right without fees (See more Law on Planning and Construction, OGRS, art. 102, no. 72/2009, 81/2009 - corr., 64/2010 - decision US, 24/2011, 121/2012, 42/2013 - decision US, 50/2013 - decision US, 98/2013 - decision US, $132 / 2014$ and $145 / 2014)$ ). It is necessary to state that the right to property is acquired on the date that the Law on Planning and Construction is put in effect. This does not apply to holders' right to use the construction land or company, as well as to all those entities on which the provisions of the law relating to privatization, bankruptcy and enforcement proceedings is applied. Article 102 of the aforementioned law provides that the aforementioned - "does not apply to persons who are holders of right to use of underdeveloped land owned by the state, which was previously governed by the applicable laws, until May 13, 2013, or on the basis of a decision of the competent authority and this land is acquired solely for the purpose of construction in accordance with regulations as set forth. "The right to use which changes into ownership right without compensation does not apply to any holders of rights to use on the construction land, whose position, i.e. status is determined by the laws governing the sport as well as associations." The negation of the right of use that is converted into property rights is applicable to companies that are marked as holders of rights to use the 
construction land. Law on Planning and Construction in Article 102, paragraph 9, item 5 states that the conversion of usage rights into property rights does not apply to - "persons, holders of rights to use the construction land on which the provisions of the regulations of the Republic of Serbia and bilateral international agreements governing the implementation of Annex G of the Agreement on succession issues (OGFRY - International treaties, no. 6/02)." The aforementioned categories of persons onto which the provisions of the Law on Planning and Construction concerning the conversion of right of usage to the right of ownership on construction land without compensation do not apply, are exclusively regulated by special laws whose legal status and position is regulated.

The Law on Planning and Construction overlooks the definition of "unity of property", which means that upon completion of the conversion of rights to use into the right of ownership of construction land existing cadastral parcel of developed construction land, built with all the objects in it becomes a unique item of property rights and thus establishes the unity of property. The point is that all the existing charges, existing on the land and the associated rights that relate to the land or its specific part, from the time of registration of ownership are transferred to the cadastral parcel, i.e. on the part of the cadastral parcel of the specific part owner. In the event that there is a long-term lease of the land in accordance with the Law on Planning and Construction the above-mentioned cannot be applied. The stated law also deals with different issues and instances of unity of property regulation, in cases where there are multiple objects of different owners built on one cadastral parcel, as well as cases when on one parcel there are several coowners and only one person being the owner of the building, and similar cases.

\section{Conversion}

Law on Planning and Construction with its amendments dated December 2014 has omitted, i.e. did not regulate the conversion for the reason that it does not have adequate analysis of the consequences of the conversion implementation, and thus leaves open the question addressing conversion. Conversion of construction land as unresolved issue presents the stumbling block for investments in Serbia and it is necessary for it to urgently solve this question. It is expected that by March 2015, a special law will be passed on conversion of land that will allow the implementation of adequate regulation and the beginning of a repurposing rights to property rights, which would necessarily entail arranging the real estate cadastre as the most important institution in the construction sector (www.mgsi.gov.rs/cir/aktuelnosti/uskoro-javna-raspravao-zakonu-o-konverziji).

Once again, we state that it is necessary to conduct the analysis of the effects of conversion based on which a special law will be passed. Conversion as a decade long question should help resolve the issues of prosperity of the construction industry. With the construction representing a prosperous economic sector it would not be unreasonable to say that there is no single segment of human creativity without this specific part of industry. However, if there is no adequate supporting legislative regulations that prosperity cannot be expected. Amendments to the most recent Law on Planning and Construction dated to 2014 introduce novelties and particularly emphasizes that everyone with the right to use has the right to build. These amendments shall be fully applied in practice through bylaws that will be brought to 
force in due time, but certainly what is already being applied in practice is the issuance of building permits for a short period of time, which will greatly speed up investments in the Republic of Serbia. The introduction of electronic building permits is expected by the end of the current year. The fundamental question of the adoption of the new Law on conversion is the analysis of the effects of the conversion of rights of use to rights of ownership on construction land because it has to consider all the effects conversion would have on the government, or what would be the result of conversion being conducted free of charge or for a fee. The next question is how high would the compensation be would be if the conversion would be implemented with the payment, and we believe that if the conversion would be conducted for a fee, this fee was would have to be minimal. Innovations that should resonate in practice and improve the construction sector are certainly related to issues of simplification procedures for obtaining building permits, and shortening the period of obtaining the license to less than a month with a "one-window" system through full implementation of the above, which is expected by mid-2015. Positive changes are related to the significant reduction in the category of debtors obliged to pay a fee for the conversion of land with the possibility of obtaining a building permit prior to completion of the conversion process.

Construction in recent years was hampered by enormous administrative and bureaucratic procedures whereas the applicable law allows a more efficient system and method to overcome this problem by applying bylaws that are expected. Applicable Amendments to the said law will improve business conditions for domestic and foreign investors. With the analysis of the effects of conversion and adoption of a special law that will regulate the issue of right to use to the right of ownership of construction land, which are in the process of privatization and have acquired the right to use land and acquire the right to build. Disposal of solutions to conversion issues will not further accelerate the issuance of building permits but will be an indicator to potential investors that the government is unable to solve this problem. As the law on the conversion of land should be adopted by the end of March 2015, it is expected that by the end of the year electronic building permit shall be available. The rapid resolution of this problem will be a confirmation to investors that the legal sector in Serbia is expeditious, which would make investing in the real estate market in the construction sector a safer activity.

\section{Conclusion}

"Construction as a complex branch of economy requires that relations of all of its participants are regulated through numerous laws and bylaws. Mutual rights and obligations of all stakeholders in works on investment and construction projects are regulated by regulating their relations inter partes on one hand and on the other huge liability towards third parties" (Drašković, 2012).

Repurposing of agricultural into construction land as the current issue needs to be seen through the necessity of applying positive legal regulations which would certainly adequately regulate this issue. Having in mind that the unresolved issue of transferring rights of usage to rights of ownership of construction land hinders investment in the Republic of Serbia, we hope that this will be the reason for the urgent adoption of a new law on conversion that would stimulate an increase in investment in the construction sector. 


\section{References}

1. Aleksić, I. R., Marošan, S. (2002): Komasacija zemljišta u zemljama centralne i istočne Evrope i zajednice nezavisnih država, Geodetska služba, vol. 31, no. 2, pp. 5-8.

2. Annex G of the Agreement on succession issues (OGFRY - International treaties, no. 6/02).

3. Union of Concerned Scientists (2014): Toward Healthy Food and Farms, portal of Union of Concerned Scientists, Washington DC, USA, segment Food \& Agriculture, available at: www.ucsusa.org/food and agriculture/

4. Avramović, M. (2004): Uređenje zemljišne teritorije komasacijom u Republici Srbiji, Geodetska služba, vol. 33, no. 1, pp. 54-68.

5. Drašković, B. (2012): Viša sila u građevinarstvu kao izuzetni događaj ili okolnost, Zbornik radova, VIII međunarodni naučno-stručni skup Savremena teorija I praksa u građevinarstvu, april 2012, Banja Luka, pp. 447-452.

6. Karolić, R. (2012): Veličina poseda i produktivnost: Poljoprivreda u Srbiji i Evropi, portal Balkan magazine, 21.septembar 2012, available at: www.balkanmagazin.net/naukal cid144-47315/velicina-poseda-i-produktivnost-poljoprivreda-u-srbiji-i-evropi

7. Lilić, S. (2010): Ekološko pravo, Pravni fakultet Univerziteta u Beogradu, Beograd, p. 227.

8. Marošan, S., Šoškić, M. (2006): Aktivnosti na unapređenju procesa komasacije u Srbiji, Geodetska služba, vol. 35, no. 105, pp. 21-24.

9. Ministarstvo građevinarstva, saobraćaja i infrastructure, Beograd, Srbija, available at: www.mgsi.gov.rs/cir/aktuelnosti/uskoro-javna-rasprava-o-zakonu-o-konverziji

10.The Draft Strategy for Agriculture and Rural Development of Serbia 2014-2024. November 2013, Ministry of Agriculture, Forestry and Water Management of the Republic of Serbia, Official Gazette of Republic of Serbia (OGRS), no. 85/2014.

11. National Rural Development Program 2011-2013 of the Republic of Serbia, Official Gazette of Republic of Serbia, no. 15/2011.

12. Nikolić Đorđić, E., Mutavdžić, B. (2014): Koncentracija distribucije poljoprivrednih gazdinstava regiona Srbije prema veličini korišćenog poljoprivrednog zemljišta, Zbornik radova - Primena podataka Popisa poljoprivrede u analizi stanja poljoprivrede i u planiranju agrarne politike u Republici Srbiji, Maj 2014, Subotica, SORS Beograd, p. 176.

13.Paraušić, V., Cvijanović, D. (2014): Ekonomska veličina poljoprivrednih gazdinstava u Srbiji i preporuka mera za njihovo osnaživanje, Zbornik radova - Primena podataka Popisa poljoprivrede u analizi stanja poljoprivrede i u planiranju agrarne politike u Republici Srbiji, Maj 2014, Subotica, SORS Beograd, pp. 25-42.

14. Stojkov, B. (2007): Ka recikliranju građevinskog zemljišta u Srbiji, Glasnik Srpskog geografskog društva, vol. 87, no. 2, pp. 175-186.

15. Tica, N., Milić, D., Zekić, V. (2009): Prinosna vrednost građevinskih objekata u poljoprivredi, Agroekonomika, no. 41-42, pp. 133-139. 
Legislation

16. Agricultural Land Law, Official Gazette of Republic of Serbia (OGRS), no. 62/2006, 65/2008, - other laws and 41/2009.

17.Law on Agricultural and Rural Development, Official Gazette of Republic of Serbia (OGRS), no. 41/2009 and 10/2013.

18.Law on Forests, Official Gazette of Republic of Serbia (OGRS), no. 30/2010.

19.Law on Public Property, Official Gazette of Republic of Serbia (OGRS), no. 72/2011, $88 / 2013$ and 105/2014.

20.Law on Planning and Construction, Official Gazette of Republic of Serbia (OGRS), no. 72/2009, 81/2009 - corr., 64/2010 - decision US, 24/2011, 121/2012, 42/2013 - decision

US, 50/2013 - decision US, 98/2013 - decision US, 132/2014 and 145/2014.

\title{
PROMENA NAMENE POLJOPRIVREDNOG ZEMLJIŠTA U GRAĐEVINSKO - PRAKSA I TENDENCIJE
}

\author{
Milan Počuča ${ }^{3}$, Bojana Draškovič ${ }^{4}$
}

\begin{abstract}
Rezime
Očuvanje poljoprivrednog zemljišta kao imperativ prosperiteta poljoprivrede Republike Srbije nužno je posmatrati i kroz uzročno-posledična pitanja kao što su promena namene poljoprivrednog zemljišta u građevinsko zemljište koju nužno prati $i$ konverzija kao decenijski problem. Nedovoljno rešena aktuelna pitanja navedenog u legislativnim okvirima otvaraju mogućnosti neadekvatnog korišćenja i eksploatisanja poljoprivrednog zemljišta. Neophodno je putem pozitivno-pravnih propisa regulisati pitanje konverzije građevinskog zemljišta, tj. prava korišćenja u pravo svojine na građevinskom zemljištu i time otvoriti put investicijama u Republici Srbiji. Uz analizu efekata konverzije i uz donošenje posebnog zakona o tom aktuelnom pitanju sama građevinska delatnost bi dodatno prosperirala. Cilj ovog rada je sagledavanje na adekvatan način aktuelne problematike konzumacije, očuvanja $i$ vršenja prenamene poljoprivrednog zemljišta u građevinsko, uz prikaz činjeničnog stanja, prakse i tendecija.
\end{abstract}

Ključne reči: poljoprivredno zemljište, građevinsko zemljište, prenamena, konverzija, urbanizacija.

3 Prof. dr Počuča Milan, vanredni profesor, Univerzitet Privredna akademija, Pravni fakultet za privredu i pravosuđe Novi Sad, Geri Karolja 1, 21000 Novi Sad, Srbija, Telefon: +381 21400 499, E-mail: pocucabmilan@gmail.com

4 Doc. dr Drašković Bojana, Univerzitet Union Nikola Tesla, Fakultet za graditeljski menadžment, Cara Dušana 62-64, 11000 Beograd, Srbija, Telefon: +381 112180 287, E-mail: bdraskovic@krstarica.com 